\title{
PENGARUH WAKTU PENYIMPANAN TERHADAP JUMLAH ERITROSIT DARAH DONOR
}

\author{
Tadjuddin Naid, Dzikra Arwie, dan Fitriani Mangerangi \\ Fakultas Farmasi Universitas Hasanuddin, Makassar \\ Email : tadjuddinnaid@yahoo.co.id
}

\begin{abstract}
A research about the effect of blood storage time to the number of erythrocyte cell count in blood donors has been done at Transfusion Blood laboratory Unit and of laboratoriun Health Of Job Society. This research is aimed to determine the effect of blood storage time to the number of erythrocyte cell count in blood donors which placed at $4^{\circ} \mathrm{C}$. This study used experiment laboratory method, with total samples are 5 bags of blood. The result of the research about eritrocyte cell count decresed every week, 4,72\% (man) and 5,45\% (woman) at the first week, 8,83\% (man) and 10,9\% (woman) at the second week, 14,17\% (man) and 15,53\% (woman) at the third week, $21,77 \%$ (man) and 25,34\% (woman) at the fourth week and 30,39\% (man) and $32,7 \%$ (woman) at the fifth week.
\end{abstract}

Keywords : storage time, caffeine, erythrocyte, blood donor

\section{PENDAHULUAN}

Darah merupakan jaringan cair yang terdiri atas dua bagian yang mempunyai banyak fungsi didalam tubuh manusia, antara lain : merupakan alat transpor, mempertahankan lingkungan dalam tubuh agar terjaga konstan dan berperan penting pada pertahanan tubuh terhadap partikel-partikel asing (1). Eritrosit atau sel darah merah memegang peranan penting dalam transport $\mathrm{O}_{2}$ dan $\mathrm{CO}_{2}$ antara paru-paru dan jaringan. Eritrosit mempunyai diameter sekitar 7 mikron berbentuk cakram kecil bikonkaf. Eritrosit terbungkus dalam membran sel dengan permeabilitas tinggi. Membran ini elastis dan fleksibel sehingga memungkinkan eritrosit dapat menembus kapiler (2).

Donor darah merupakan individu atau orang yang menyumbangkan darahnya dengan tujuan untuk membantu yang lain khususnya yang memerlukan suplai darah dari luar. Darah yang dihasilkan biasanya disimpan di Bank Darah untuk kemudian dipakai pada transfusi darah (3). 
Penyimpanan darah harus dijaga pada suhu $\pm 4^{\circ} \mathrm{C}$. Alasan utama pemberian transfusi darah adalah untuk mempertahankan kemampuan tubuh dalam menyalurkan oksigen ke organ-organ yang membutuhkan. Selain itu juga untuk menjaga volume darah yang terdapat dalam tubuh. Apabila darah tidak disimpan pada suhu $\pm 4{ }^{\circ} \mathrm{C}$, kemampuannya untuk menyalurkan oksigen akan sangat berkurang (4).

Darah lengkap yang disimpan dalam lemari pendingin mempunyai waktu paruh 35 hari. Selama penyimpanan sel darah merah sangat sensitif terhadap pembekuan. Apabila sel darah merah membeku, maka dinding sel darah akan pecah dan haemoglobin akan keluar. Keadaan ini dapat berakibat fatal bagi penerima transfusi darah (4).

Pemberian darah lengkap kepada penderita dapat memperbaiki volume darah dan kapasitas angkut oksigen dan merupakan cara yang paling baik dalam mengatasi kehilangan darah yang berlebihan. Namun pemberian darah dengan volume darah yang cukup tetapi kekurangan eritrosit dan protein (hemoglobin), akan kurang mendapat manfaat dari transfusi yang dilakukan (5).
Berdasarkan pemaparan di atas, maka perlu dilakukan penelitian yang bertujuan untuk mengetahui pengaruh waktu penyimpanan darah donor terhadap jumlah eritrosit yang disimpan pada suhu suhu $\pm 4{ }^{\circ} \mathrm{C}$.

\section{METODE PENELITIAN}

\section{A. Jenis Penelitian}

Jenis penelitian ini adalah eksperimen laboratorik yang menggunakan darah donor sebagai sampel penelitian.

\section{B. Tempat dan Waktu Penelitian}

Penelitian ini dilakukan di Unit Transfusi Darah (UTD) Prov. Sulsel dan Balai Kesehatan Kerja Masyarakat Prov.Sulsel.

Waktu penelitian dilakukan pada tanggal 26 september sampai 31 Oktober 2011.

\section{Populasi dan Sampel Penelitian}

Subjek penelitian adalah orang yang datang ke Unit Transfusi Darah (UTD) Provinsi Sulawesi Selatan yang ingin mendonorkan darahnya. Sampel yang digunakan dalam penelitian ini diambil secara acak sebanyak 5 kantong darah dengan 30 kali perlakuan.

\section{Kriteria Sampel}

Kriteria inklusi : orang yang melakukan donor darah di Unit 
Transfusi Darah, laki-laki dan perempuan berumur 17 - 60 tahun dengan berat badan tidak kurang dari $45 \mathrm{Kg}$, kadar HB normal, dan riwayat medis tidak terinfeksi penyakit menular seperti hepatitis, sifilis, AIDS.

Kriteria eksklusi : sampel mengalami hemolisis dan sampel beku.

\section{E. Alat dan Bahan}

Alat-alat yang digunakan adalah tabung sampel, Medonic Hematology Analyzer, dan lemari pendingin/electrolux refrigerator.

Bahan yang digunakan adalah darah donor dengan antikoagulan.

\section{F. Prosedur Kerja}

\section{Cara Memperoleh Sampel Darah}

Pendonor yang telah memenuhi persyaratan donor darah segera diambil darahnya dengan cara menusuk vena dengan jarum bloodbag maka darah akan mengalir masuk ke kantong darah yang telah berisi antikoagulan CPDA. Pada saat proses pengisian darah kantong darah harus selalu digoyang supaya antikoagulan dan darah dapat tercampur rata. Volume darah yang diambil sejumlah \pm
250 cc. Setelah volume terpenuhi maka proses pengaftapan/pengambilan darah dihentikan. Sisa darah yang berada dalam selang kantong darah diserut dengan handsealer dan dimasukkan kedalam kantong darah sehingga dapat tercampur dengan antikoagulan (6).

2. Penyimpanan darah donor

Diperiksa terlebih dahulu suhu lemari pendingin/ refrigerator. Tempatkan darah pada bag holder dengan suhu $4^{\circ} \mathrm{C}$ dan disimpan selama 1 minggu, 2 minggu, 3 minggu, 4 minggu, dan 5 minggu.

3. Prosedur

Pemeriksaan

\section{Eritrosit Darah Donor}

Setelah 1 minggu sampel dikeluarkan dari refrigerator dan didiamkan sampai suhu kamar terlebih dahulu, dihomogenkan darah yang akan diukur dan masukkan kedalam tabung sampel \pm 3 cc. Setelah itu diperiksa dengan alat Hematology Analyzer kemudian dicatat hasil pengukuran jumlah eritrositnya.

Setelah 2 minggu penyimpanan, sampel dikeluarkan lagi dari 
refrigerator, diamkan pada suhu kamar lalu dimasukkan kedalam tabung kemudian dilanjutkan pada pemeriksaan alat Hematology Analyzer sampai diperoleh hasil. Begitupun prosedur pemeriksaan eritrosit pada penyimpanan minggu ke3 , minggu ke-4, maupun minggu ke-5.

4. Pemeriksaan darah donor dengan alat Medonic Hematology Analyzer

Pada alat tekan "ID/SEQ" muncul "PAD/ID?" Isikan No/nama pasien, "Current" bila "Exit" : ESC, "Save": enter, lalu enter. Muncul "Press The Sampling Bar" dan tunggu needle sampling muncul. Dikocok lagi darah sampai homogen, masukkan needle sampling ke dalam darah, tekan klik pada bagian belakang needle sampling. Tunggu 1 menit Analyzer melakukan pengukuran. Pada layar "Printing Result", lalu "Sending Result", kemudian alat akan memprint out hasil pengukuran (7).

\section{G. Analisis Data}

Data yang diperoleh, dianalisis secara deskripsi untuk melihat pengaruh waktu penyimpanan terhadap jumlah eritrosit darah donor.

\section{HASIL PENELITIAN}

Hasil penelitian menunjukkan bahwa jumlah eritrosit pada darah donor yang disimpan pada lemari pendingin atau refrigerator dengan suhu $4^{\circ} \mathrm{C}$ selama 5 minggu mengalami penurunan jumlah.

Lima kantong darah, yang terdiri atas 2 kantong darah dari jenis kelamin perempuan dan 3 kantong darah dari jenis kelamin laki-laki. Kemudian dilakukan pemeriksaan eritrosit dengan 30 kali perlakuan dan hasilnya dapat dilihat pada tabel berikut:

Tabel 1. Distribusi Hasil Pemeriksaan Eritrosit

\begin{tabular}{|c|c|c|c|c|c|c|c|}
\hline \multirow{3}{*}{ No } & \multirow{3}{*}{ Hari/ Tanggal } & \multicolumn{5}{|c|}{ Hasil Pemeriksaan Eritrosit (juta per $\mathbf{m m}^{3}$ ) } & \multirow{3}{*}{$\begin{array}{c}\text { Lama } \\
\text { Penyimpanan }\end{array}$} \\
\hline & & \multicolumn{2}{|c|}{ Perempuan } & \multicolumn{3}{|c|}{ Laki - Laki } & \\
\hline & & Sampel 1 & Sampel 2 & Sampel 3 & Sampel 4 & Sampel 5 & \\
\hline 1. & $\begin{array}{c}\text { Senin } \\
26-09-2011\end{array}$ & 3,84 & 3,47 & 4,56 & 5,24 & 4,80 & Hari I \\
\hline 2. & $\begin{array}{c}\text { Senin } \\
03-10-2011\end{array}$ & 3,64 & 3,29 & 4,33 & 5,05 & 4,56 & Minggu I \\
\hline 3. & $\begin{array}{c}\text { Senin } \\
10-10-2011\end{array}$ & 3,45 & 3,12 & 4,10 & 4,91 & 4,32 & Minggu II \\
\hline 4. & $\begin{array}{c}\text { Senin } \\
17-10-2011\end{array}$ & 3,26 & 2,94 & 3,87 & 4,60 & 4,08 & Minggu III \\
\hline 5. & $\begin{array}{c}\text { Senin } \\
24-10-2011\end{array}$ & 2,88 & 2,6 & 3,42 & 4,42 & 3,6 & Mnggu IV \\
\hline
\end{tabular}




\begin{tabular}{|c|c|c|c|c|c|c|c|}
\hline 6. & $\begin{array}{c}\text { Senin } \\
31-10-2011\end{array}$ & 2,59 & 2,34 & 3,08 & 3,86 & 3,24 & Minggu V \\
\hline
\end{tabular}

diketahui bahwa nilai rata-rata juta sel per $\mathrm{mm}^{3}$ (15,53\%), mulai pemeriksaan eritrosit pada perempuan menunjukan perubahan nilai eritrosit mengalami penurunan tiap minggunya dimana pada penyimpanan minggu dibawah nilai normal, yaitu 3,2-5,2 juta sel per $\mathrm{mm}^{3} \quad$ (Grafik

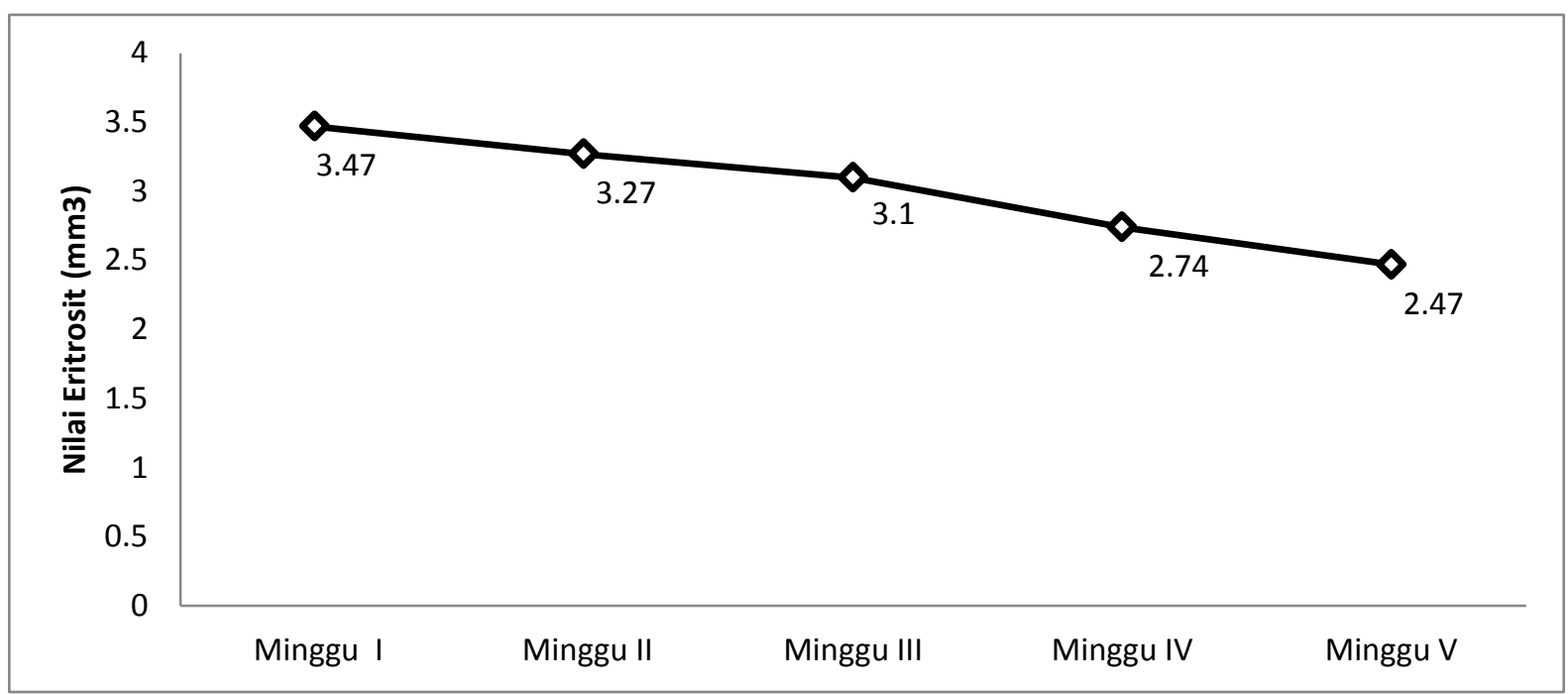

Gambar 1. Grafik rata-rata nilai eritrosit tiap minggu pada perempuan

Penurunan nilai rata-rata masa penyimpanan. Untuk lebih eritrosit tersebut disertai dengan jelasnya dapat dilihat pada grafik peningkatan persentase kehilangan gambar 2 dibawah ini:

nilai eritrosit atau lisis eritrosit selama

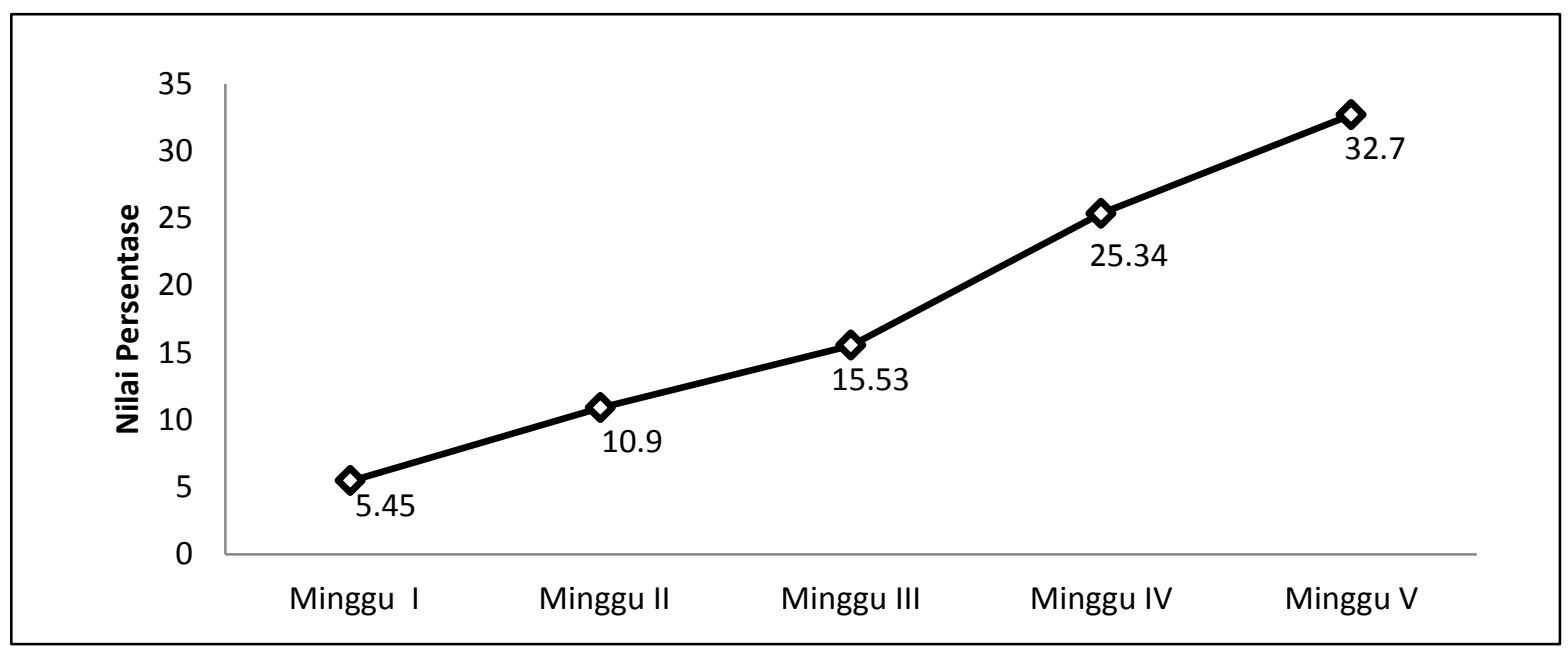

Gambar 2. Grafik persentase nilai eritrosit yang lisis tiap minggu pada perempuan 
Sedangkan pada laki-laki nilai juta sel per $\mathrm{mm}^{3}(14,17 \%)$ yang berarti rata-rata hasil pemeriksaan eritrositnya dibawah nilai normal (4,2-5,5 juta sel juga menunjukkan penurunan nilai per $\mathrm{mm}^{3}$ ). Hasil pengukuran nilai rataeritrosit tiap minggunya dan pada rata eritrosit pada laki-laki dapat dilihat minggu ke-III nilai eritrosit yaitu 4,18 pada grafik gambar 3 berikut :

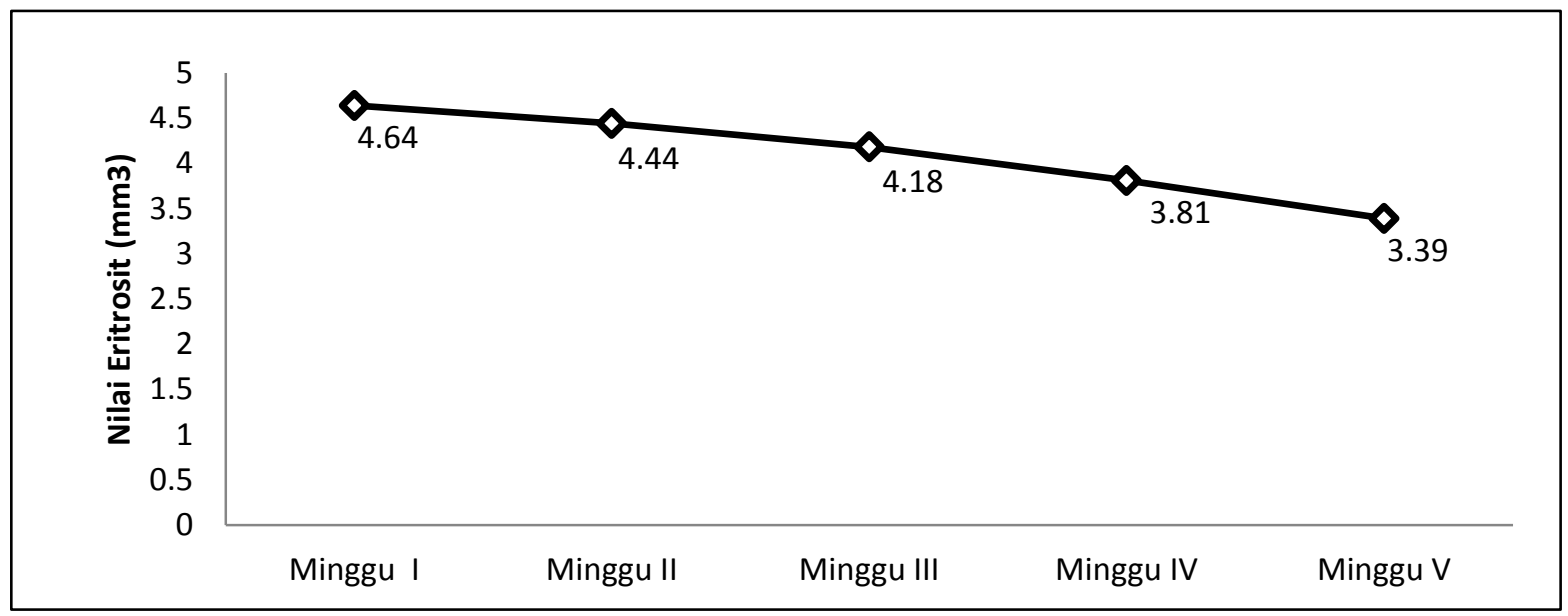

Gambar 3. Grafik rata-rata nilai eritrosit pada laki-laki tiap minggu

Hal yang sama juga terjadi pada peningkatan persentase kehilangan jenis kelamin laki-laki dimana penurunan nilai rata-rata eritrosit selama penyimpanan disertai dengan atau lisis nilai eritrosit. Untuk lebih jelasnya dapat dilihat pada grafik gambar 4 dibawah ini:

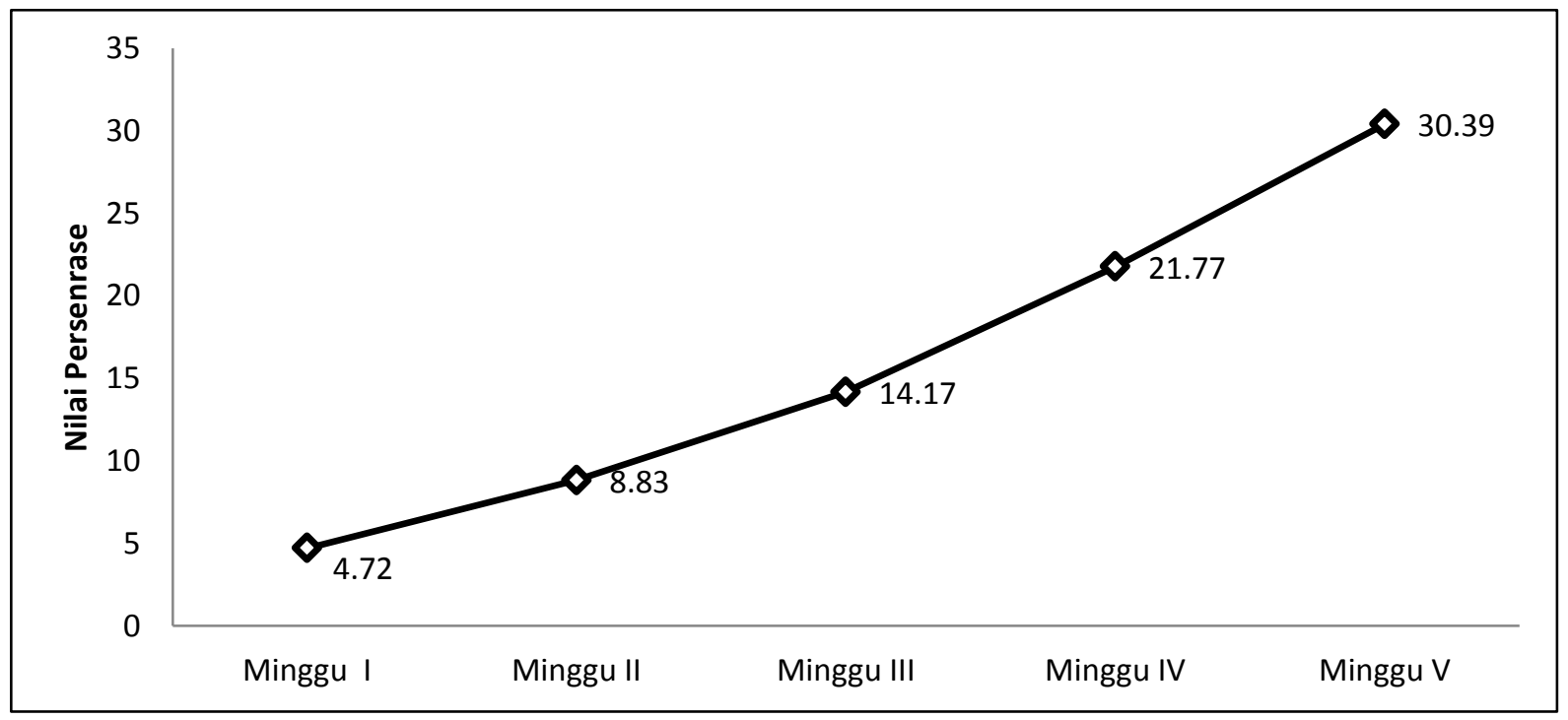

Gambar 4. Grafik persentase nilai eritrosit yang lisis pada laki-laki tiap minggu 


\section{PEMBAHASAN}

Secara invivo atau dalam tubuh manusia, sel darah dalam keseimbangan yang dinamis yaitu keseimbangan antara pembentukan (produksi) dan penghancuran (destruksi). Sel darah memerlukan energi untuk mempertahankan bentuk sel dan melakukan fungsi sel. Untuk mendapatkan energi, maka sel memerlukan bahan-bahan serta oksigen untuk dapat melakukan metabolisme. Sedangkan darah secara invitro atau diluar tubuh seperti dalam kantung darah, tidak ada keseimbangan antara produksi dan destruksi. Melainkan hanya ada destruksi tanpa ada produksi sehingga proses penghancuran terjadi lebih cepat (8).

Dengan demikian tujuan penyimpanan darah secara invitro dengan proses yang khusus adalah untuk memperlambat proses penghancuran sel darah. Oleh karena itu, dalam penelitian ini darah invitro atau dalam kantung darah disimpan pada suhu yang rendah yaitu $4^{\circ} \mathrm{C}$ dalam lemari pendingin atau Electrolux Refrigerator. Selain itu untuk memperlambat perubahan yang terjadi selama penyimpanan, ditambahkan antikoagulan Citrat Phosphat Dextrosa Adenin (CPDA) yang dapat mencegah terjadinya pembekuan darah dan mempertahankan kadar Adenosin Triphosphat (ATP) dalam darah sampai 35 hari penyimpanan atau selama 5 minggu (8).

Menurut Pramudji Hastuti, penyimpanan darah dengan antikoagulan CPDA menyebabkan penurunan kadar ATP yang sangat banyak pada minggu ketiga dan keempat (9). Dan hal ini terbukti pada penelitian yang telah dilakukan yaitu menunjukan penurunan eritrosit pada penyimpanan minggu ke-III.

Berdasarkan data hasil pemeriksaan eritrosit pada 30 kali perlakuan diperoleh rata-rata dan presentase nilai eritrosit pada laki-laki 4,64 juta/sel $\mathrm{mm}^{3}(4,72 \%)$ di minggu pertama kemudian mengalami penurunan jumlah tiap minggunya yaitu 4,44 juta/sel $\mathrm{mm}^{3}$ (8,83\%) pada minggu kedua dan 4,18 juta/sel $\mathrm{mm}^{3}$ $(14,17 \%)$ pada minggu ketiga. Memasuki minggu keempat nilai rataratanya menjadi 3,81 juta/sel $\mathrm{mm}^{3}$ dengan persentase $21,77 \%$ dan pada minggu kelima penyimpanan diperoleh 3,39 juta/sel mm $\mathrm{mm}^{3}(30,39 \%)$. 
Di minggu pertama, pada perempuan menunjukkan 3,47 juta/sel $\mathrm{mm}^{3}(5,45 \%)$ dan 3,27 juta/sel $\mathrm{mm}^{3}$ $(10,9 \%)$ di minggu kedua, namun nilai ini masih dalam batas normal. Minggu ketiga rata-ratanya menjadi 3,1 juta/sel $\mathrm{mm}^{3}(15,53 \%)$ hal ini sudah mulai menunjukkan penurunan nilai eritrosit dibawah batas normal, terus menerus mengalami penurunan jumlah setiap minggunya sampai pada minggu keempat nilai rata-ratanya menjadi 2,74 juta/sel $\mathrm{mm}^{3}(25,34 \%)$ dan di minggu ke lima menjadi 2,47 juta/sel $\mathrm{mm}^{3}(32,7 \%)$.

Dari uraian diatas dapat dilihat daya hidup eritrosit atau stabilitas eritrosit menurun sebanding masa simpannya, semakin lama darah donor disimpan maka semakin berkurang nilai eritrositnya. Penurunan ini disebabkan karena zat yang dibutuhkan oleh darah seperti dekstrosa yang digunakan sebagai sumber energi dalam menjaga kelangsungan hidupnya akan mengalami penurunan selama penyimpanan dan menyebabkan lisisnya eritrosit. Oleh karena itu darah lengkap yang disimpan dalam lemari pendingin dengan suhu $4^{\circ} \mathrm{C}$ selama 3 5 minggu masih mempunyai khasiat meningkatkan volume tubuh akibat perdarahan hebat tetapi kurang berkhasiat meningkatkan oksigenasi jaringan dan kurang bekhasiat juga untuk memperbaiki keadaan hemostatis di dalam tubuh.

\section{KESIMPULAN}

Berdasarkan hasil penelitian dan pembahasan, dapat disimpulkan bahwa darah donor yang disimpan pada lemari pendingin atau refrigerator dengan suhu $4^{\circ} \mathrm{C}$ mengalami penurunan nilai eritrosit tiap minggunya dimana pada penyimpanan minggu ketiga sudah mulai menunjukan penurunan nilai eritrosit dibawah nilai normal yaitu pada lakilaki 4,18 juta/ $/ \mathrm{mm}^{3}$ dengan persentase kehilangan eritrosit sebesar 14,17\% dan pada perempuan 3,1 juta/ $\mathrm{mm}^{3}$ dengan persentase kehilangan eritrosit sebesar $15,53 \%$.

\section{DAFTAR PUSTAKA}

Koolman, J., Heinrich, K, R. Atlas Berwarna dan Teks Biokimia. Terjemahan oleh Wanandi SI. Hipokrates. Jakarta. 2001.

Sloane, E. Anatomi dan Fisiologi untuk pemula. EGC. Jakarta. 2004

Triwibowo. Indikasi dan Reaksi Transfusi Darah. Komite Medis RSUP. Dr. Sardjito. Yogyakarta. 1996

Anonim. Mutu dan Keamanan Dalam Penyediaan Darah. Unit Tranfusi Darah. Jakarta. 2003 
Widman, F, K. Tinjauan Klinis atas Hasil Pemeriksaan Laboratorium. Ed. 9 . Terjemahan oleh Boedina KS, Soebrata R \& Latu J. Penerbit Buku Kedokteran. EGC. Jakarta.1995

Anonim. Kumpulan PKS Quality Assurance. Jakarta Selatan. 2006

Anonim. Operator's manual automated Hematologi analyzer Medonic. Jakarta Selatan. 2010
Rosita, R. Pelatihan Crash Program Petugas Teknis Transfusi Darah Bagi Petugas UTDRS. Departemen Kesehatan Republik Indonesia. Jakarta. 2008.

Hastuti, P. Pengaruh Penambahan ATP dan vitamin $E$ terhadap fragilitas eritrosit darah CPD donor invitro. (serial on the internet). 10 September 2011. Availabel from http://www.scribd.com 